See discussions, stats, and author profiles for this publication at: https://www.researchgate.net/publication/323428480

\title{
Is There a Resource Curse for Private Liberties? Forthcoming in International
} Studies Quarterly

Preprint · February 2018

CITATIONS

0

1 author:

Simon Wigley

Bilkent University

28 PUBLICATIONS 111 CITATIONS

SEE PROFILE

Some of the authors of this publication are also working on these related projects:

Project Democracy and health View project

Project Parliamentary Immunity View project
READS

65 


\title{
Is There a Resource Curse for Private Liberties?
}

\author{
Forthcoming in International Studies Quarterly \\ Simon Wigley \\ Department of Philosophy \\ Bilkent University \\ wigley - at - bilkent.edu.tr
}

18 February 2018

\begin{abstract}
The existing literature on the political resource curse focuses on whether oil wealth hinders the transition to democracy. In this study, I examine whether oil wealth negatively affects the private rights of the individual. I argue that petroleum-rich governments are subject to less pressure to protect freedom of movement, freedom of religion, the right to property, and freedom from forced labor. In addition, they can use the windfall at their disposal to finance the enforcement of laws that restrict those private rights. Based on a panel of 162 countries for the years 1932-2003, I find that petroleum wealth is negatively associated with private liberties. Using mediation analysis, I also find that most of the impact of oil wealth on private rights arises independently of its impact on the level of democracy. This indicates that the scope of the political resource curse extends beyond representation to include the private rights of the individual.
\end{abstract}

\section{Introduction}

In this study, I demonstrate that the political resource curse is not limited to the democratic process, as many studies have shown (Ross 2015), but also affects the rights of citizens. I provide evidence that rising petroleum wealth reduces the incentive for governments to protect private rights. Those rights include freedom of movement, freedom of religion, the right to property, and freedom from forced labor. Political leaders with access to petroleum riches are less reliant on non-resource taxes in order to finance the provisioning of benefits to their backers. Thus, they need not increase the protection of rights in return for the imposition of new taxes. They can also 
use the windfall at their disposal to finance the enforcement of laws that limit the rights of the individual.

Consider the political trajectories of the Caucasian states since the collapse of the Soviet Union. The protection of private liberties rose sharply in Armenia, Georgia, and Azerbaijan after they became independent states at the start of the 1990s. That level of rights-protection has been maintained in oil-poor Armenia and Georgia over the last 25 years. However, the protection of private liberties has steadily declined in oil-rich Azerbaijan during the same period, such that it has now returned to the level it was at the time of independence. Citizens in Armenia and Georgia now enjoy more than double the level of private rights-protection than their counterparts in Azerbaijan (Coppedge et al. 2017). From 1990 to 2014 oil income in Azerbaijan increased nearly fivefold (Ross and Mahdavi 2015), due to rising petroleum prices and the development of gas fields in the Caspian Sea. As a consequence, total government expenditures rose by 600 percent between 2001 and 2009 (Ross 2012, 28). Would Azerbaijan have maintained the same level of rights protection as its regional neighbors if it did not have access to sub-soil riches? Critics may argue that governments in countries such as Azerbaijan are institutionally predisposed to both seek hydrocarbon rents and to restrict the private rights of the individual (Menaldo 2016, 181205). Thus, to establish the claim that oil wealth causes a reduction in private liberties, it is essential that I control for background factors that might encourage political leaders to simultaneously pursue oil rents and circumscribe private rights.

Petroleum wealth may also reduce the incentive for governments to increase representation, which means that citizens are less able to demand the protection of their private rights. If that is the case, the presence of a negative relationship between oil wealth and private rights is merely a byproduct of the negative impact of oil wealth on the level of democracy. Thus, to substantiate the claim that the political resource curse reaches beyond democratic processes and representation, it is also crucial that I show that oil wealth has a direct (democracyindependent) effect on private liberties.

To prove these points, I analyze a panel of 162 countries for the years 1932-2003. I find that petroleum wealth is negatively associated with private liberties. Crucially my results hold when country fixed effects and instrumental variables are used to address the possibility of omitted variable bias and reverse causation. The results are also robust to the inclusion of alternative measures of petroleum wealth and private liberties, as well as the use of multiple imputation to estimate missing values. I also use mediation analysis to present evidence that most of the impact of oil wealth on private rights arises independently of its impact on the level of democracy. 


\section{Theoretical Background}

Two arguments are typically presented in support of the claim that petroleum wealth negatively affects political institutions. The first argument appeals to the fact that political leaders in countries that lack natural resources must tax economically productive activity in order to finance the distribution of benefits to their backers. In response citizens demand greater political representation (Mahdavy 1970; Levi 1989; Ross 2012, chap. 3). By contrast, political leaders in petroleum-rich countries need not impose new taxes and, therefore, are subject to less pressure to introduce accountability. The second argument appeals to the fact that petroleum-rich governments can use the windfall at their disposal to protect themselves from being ousted. That is, they can co-opt support by providing benefits and negate potential threats by expanding the security apparatus of the state (Wright, Frantz, and Geddes 2015). The prediction that emerges from these two mutually supporting arguments is that petroleum-rich autocracies are less likely to transition to democratic rule.

The question I consider in this study is whether those two lines of argument also apply to the private rights of the individual. If citizens demand greater responsiveness and accountability in return for the levying of new taxes, then it seems plausible that they will also demand the expansion of their private liberties. In keeping with that suggestion, North and Weingast (1989) have argued that the English crown's growing need for revenue during the seventeenth century led to reforms that afforded greater protection to private rights and, ultimately, a permanent role for Parliament in political decision-making. In fact, it is possible that citizens will prioritize civil rights over representation because such rights directly protect them from interference by the government. Equally, political leaders that are under pressure to institute political reform may prefer to increase the protection of civil rights, rather than to increase accountability (O'Donnell and Schmitter 1986, 9-10). By contrast, political leaders with access to lucrative natural resources can avoid imposing non-resource taxes and, therefore, are subject to less pressure to increase the protection of civil rights. They may also circumscribe the civil rights of citizens so as reduce the likelihood of a successful coup or revolution. Equally, they may limit some of those rights in order to increase the benefits accruing to themselves and their backers (e.g. confiscation of private property and restriction of workers' rights). With both those goals in mind, political leaders may use oil rents to finance the expansion of the state's security apparatus.

Thus, I contend that the arguments that scholars have used to predict a negative association between oil wealth and democracy, also predict a negative association between oil wealth and private liberties. The theory presented above also implies a direct pathway between 
oil wealth and private rights. Citizens in resource-poor countries demand more private rights, independently of their demand for greater representation. An alternative explanation is that citizens demand more representation, which thereby enables them to demand more private rights. Thus, I also examine whether there is a direct effect of oil wealth on private liberties and, if so, the magnitude of that effect when compared with the indirect (democracy-mediated) effect of oil wealth on private liberties.

\section{Existing Studies}

There are a number of cross-national studies that show a positive association between petroleum wealth and the persistence of autocratic rule (Ross 2015). However, critics argue that those studies are susceptible to post-treatment bias, omitted variable bias, and simultaneous causation. Herb (2005), for example, contends that those studies that include GDP per capita as a control variable, effectively exclude the potentially salutary impact of oil rents on regime-type via income growth. Haber and Menaldo (2011) contend that oil income and regime-type are jointly determined by pre-existing state capacity. Similarly, Menaldo (2016, chap. 5) argues and presents evidence for the view that countries characterized by weak institutions expend more effort exploring for oil and gas deposits and extract at a higher rate than those countries with strong institutions.

Two cross-national studies that include country fixed-effects and instrumental variables in order to address the possibility of omitted variable bias and reverse causation, find evidence that oil rents are actually associated with democratic improvement (Haber and Menaldo 2011; Menaldo 2016, chap. 6). Liou and Musgrave (2014) compare the impact of the 1973 oil-price shock on the regime-type of newly resource-reliant countries with a synthetic counterfactual constructed based on resource-deprived countries. Based on that comparison they find little evidence that an exogenous boost in oil revenues hinders democratization.

In the analysis that follows I employ model specifications that include country fixedeffects and instrumental variables to examine the impact of oil wealth on private liberties. I also examine whether the results hold when GDP per capita is excluded as a control variable. This enables us to observe whether the direct negative impact of petroleum wealth is offset by the indirect positive impact of petroleum wealth (e.g. via economic growth).

\section{Measuring Private Liberties}

The indicators of private rights that are used in this study are drawn from the unique database of political variables that has recently been constructed by the Varieties of Democracy project (V- 
Dem). The data set covers 162 countries, stretching as far back as 1900. It, therefore, permits us to examine the impact of oil on private liberties from the period when countries first started to produce economically significant quantities of oil (Andersen and Ross 2014, 997-98). In addition, it avoids the methodological problems that afflict existing indices (Coppedge et al. 2011; Munck and Verkuilen 2002; Skaaning 2009). Each variable is constructed based on coding by multiple country experts and uses cross-rater disagreement to estimate, and thereby correct for, measurement error. Scale consistency between indicators is achieved by converting ordinal ratings into interval-level estimates of each latent concept (e.g. freedom of movement) (Coppedge et al. 2017a).

The V-Dem project includes an index of private liberties, which is based on four subcomponents: freedom from forced labor, freedom of religion, freedom of movement, and property rights. It is important to note that each component is based on actual practices (de facto), rather than formal legal rights (de jure) (Coppedge, et al. 2017b).

Private rights are not directly connected with the democratic process. Typically, they are construed as rights that place limits on democratic decision-making, rather than as rights that safeguard the democratic process itself (Dahl 1991, 116, 169-73). Those scholars that investigate the political resource curse almost exclusively focuses on democratic procedures and, especially, the degree to which those procedures enable electoral participation and multi-party competition. This means that they, at least implicitly, take into account those rights that are essential to the democratic process (e.g. the right to vote, right to stand for public office, freedom of political association, etc.). In other words, they examine whether hydrocarbon wealth leads to legislation that restricts what we might call the procedural rights of the individual. ${ }^{1}$

The dashed line in figure 1 is the average private liberties score for the 14 countries included in the V-Dem dataset that have consistently produced at least 100 constant dollars per capita in oil income since $1970 .^{2}$ The solid line in the graph represents the average private liberties score for the remaining countries in the world. As we can also see, the oil-producing countries have underperformed relative to the rest of the world throughout the post-war period and the divergence has increased since the early 1970s. Two factors might explain this

\footnotetext{
${ }^{1}$ Two studies show that oil wealth leads to less media freedom and government transparency, thereby reducing the accountability of political leaders (Egorov, Guriev, and Sonin 2009; Vadlamannati and De Soysa 2016). In both cases the impact of oil rents on the quality of the democratic process remains the central issue.

${ }^{2}$ The 14 oil producers are Algeria, Canada, Gabon, Iran, Iraq, Kuwait, Libya, Oman, Qatar, Russia, Saudi Arabia, Trinidad and Tobago, United States, and Venezuela. In the online appendix (section A.3) I construct the same graph using fiscal reliance on oil revenues to identify oil states. The observed trend is similar to that found in Figure 1.
} 
divergence. In the first place, the 1973 and 1979 oil-price shocks significantly boosted the oil revenues of oil-producing states. In the second place, virtually all oil-exporting countries nationalized their oil industries between the late 1960s and the late 1970s, meaning that political leaders in those countries were able to capture even more oil rents (Andersen and Ross 2014, 1001-2). As a result, they were increasingly able to provide benefits to their backers without imposing taxes, thereby reducing the need to strike a political bargain with citizens.

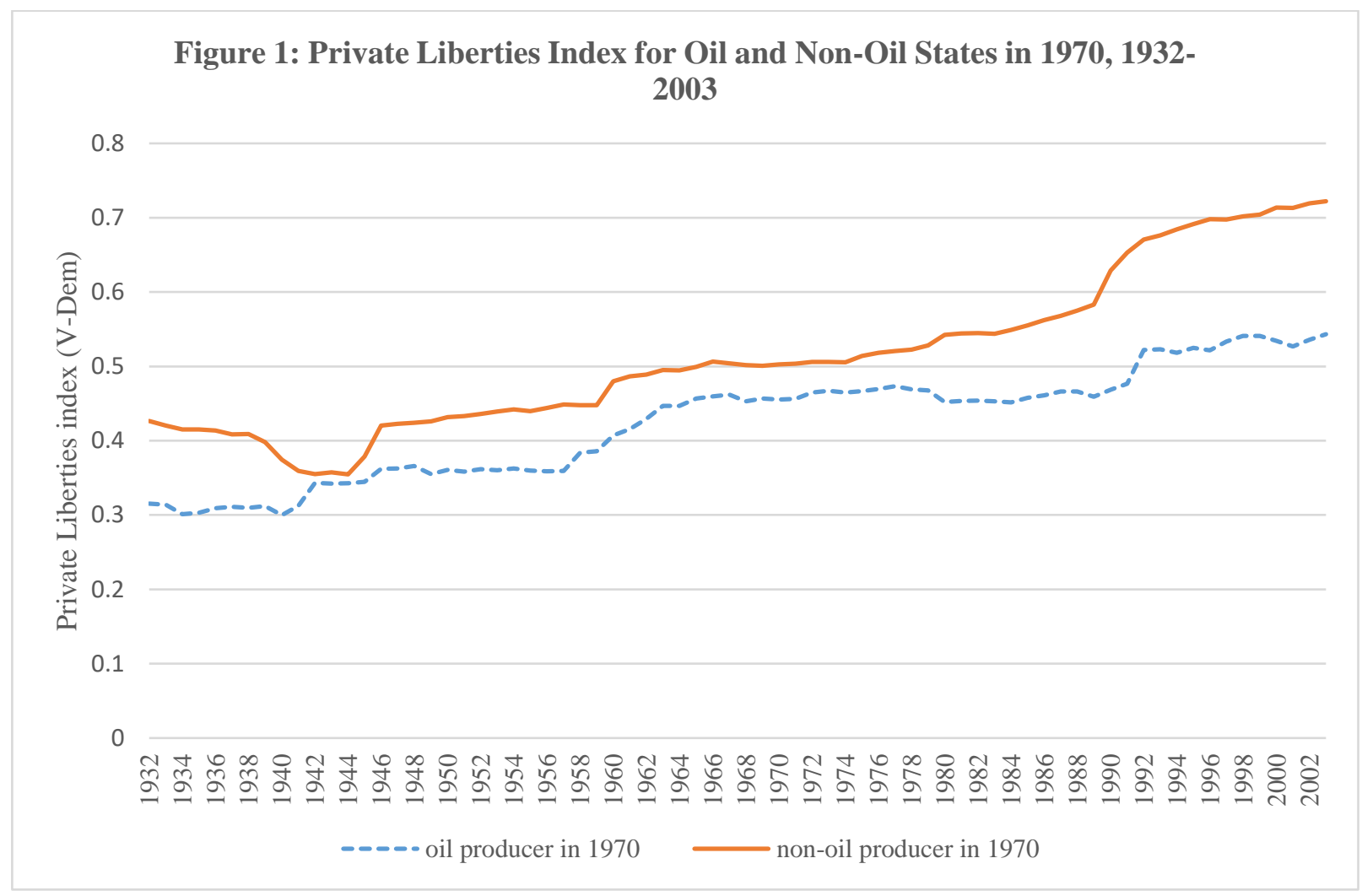

\section{Resource Boom Collapse and Political Reform}

Most of the existing resource curse literature focuses on the impact of rising oil revenues on political institutions. Less attention has been devoted to examining the political impact of declining oil revenues. This is primarily because the ever-growing demand for oil and gas has led to a significant increase in the number of oil-producing states. Between 1960 and 2006 the number of countries producing economically significant quantities of oil rose from 11 to 49 (Andersen and Ross 2014, 997). The growing demand for petroleum also enabled most petroleum-abundant states to maintain substantial revenues over time. A partial exception to this trend is provided by those resource-reliant countries that experience a precipitous decline in oil revenues as a result of a slump in world oil prices. In such cases political leaders increasingly lose the capacity to purchase support without imposing new non-resource taxes. The resulting 
decline in benefits, or rise in the tax burden, may lead citizens to demand an increase in rightsprotection and representation.

With that in mind, I examine the impact of the decline in oil prices during the 1980s on those states that were heavily reliant on oil and gas revenues at the beginning of that decade. I classify a country as heavily reliant if oil revenues represented at least $60 \%$ of total government revenues in 1980. ${ }^{3}$ Those countries are Algeria, Angola, Republic of Congo, Gabon, Indonesia, Iran, Trinidad and Tobago, Kuwait, Libya, Nigeria, Oman, Qatar, Saudi Arabia, and Venezuela. After peaking in 1980 world oil prices declined rapidly, dropping by more than half in 1986 alone (British Petroleum 2016). This had a dramatic effect on government revenues in resourcereliant countries, especially the first seven countries listed above. For those seven countries the share of petroleum revenues in total government revenues fell from above $60 \%$ in 1980 to below $40 \%$ in 1988. As we can see from figure 2 there was a noticeable uptick in the average level of private liberties for those seven countries from 1988 onward, which has continued into this century. This was not the case, however, for those seven heavily oil-reliant states that were less affected by the slump in oil prices after $1980 .^{4}$

Figure 2 also includes the average democracy score for both sets of states. ${ }^{5}$ That score increased at the end of the 1980s for those countries most affected by the slump. However, it is noteworthy that the uptick in democracy was less pronounced than was the case for private liberties, and that the two indicators have continued to diverge since the early 1990s. This is consistent with the claim that citizens prioritize individual rights over representation because they afford them direct protection from government interference. However, it is also consistent with the claim that political leaders that need to introduce political reform in order to placate a dissatisfied citizenry prefer to grant more private rights than to increase accountability. Indeed,

\footnotetext{
3 This measure of fiscal reliance on oil and gas revenues is taken from the data sets constructed by Haber and Menaldo (2011) and Richter and Lucas (2016) (variable names, respectively, fiscal reliance and roilgas_0_REV).

${ }^{4}$ The share of oil revenues in total government revenues did not fall below $66 \%$ in Kuwait, Nigeria, Oman, Qatar and Saudi Arabia during the 1980s. In Venezuela it did not fall below 47\%. Libya is a borderline case because oil reliance in that country fell from $85 \%$ in 1980 to as low as $41 \%$ in 1988 . However, the overall trend was unchanged when I excluded that country from the analysis.

5 This measure of democracy is taken from the V-Dem project and takes into account degree of suffrage, freedom of political and civil organization, whether the chief executive is selected through popular elections and the extent to which elections are free and fair (Coppedge, et al. 2017b) (variable name: v2x_EDcomp_thick).
} 
both factors combined may explain the divergent trajectories after $1988 .{ }^{6}$ Finally, figure 2 demonstrates that the average democracy score for those countries that were less severely affected by the slump has remained largely unchanged throughout the entire period.

It is possible that the seven states that were significantly affected by the price slump were influenced by the wave of political reform that began to take place across the world at the end of the 1980s (see figure 1). However, the comparison with the seven oil-reliant states that were less affected by the price slump suggests that declining oil revenues during the 1980s was also a key factor. That is to say, the maintenance of substantial oil revenues over time may have allowed the political leaders in those countries to resist internal and external pressure to increase the protection of individual rights.

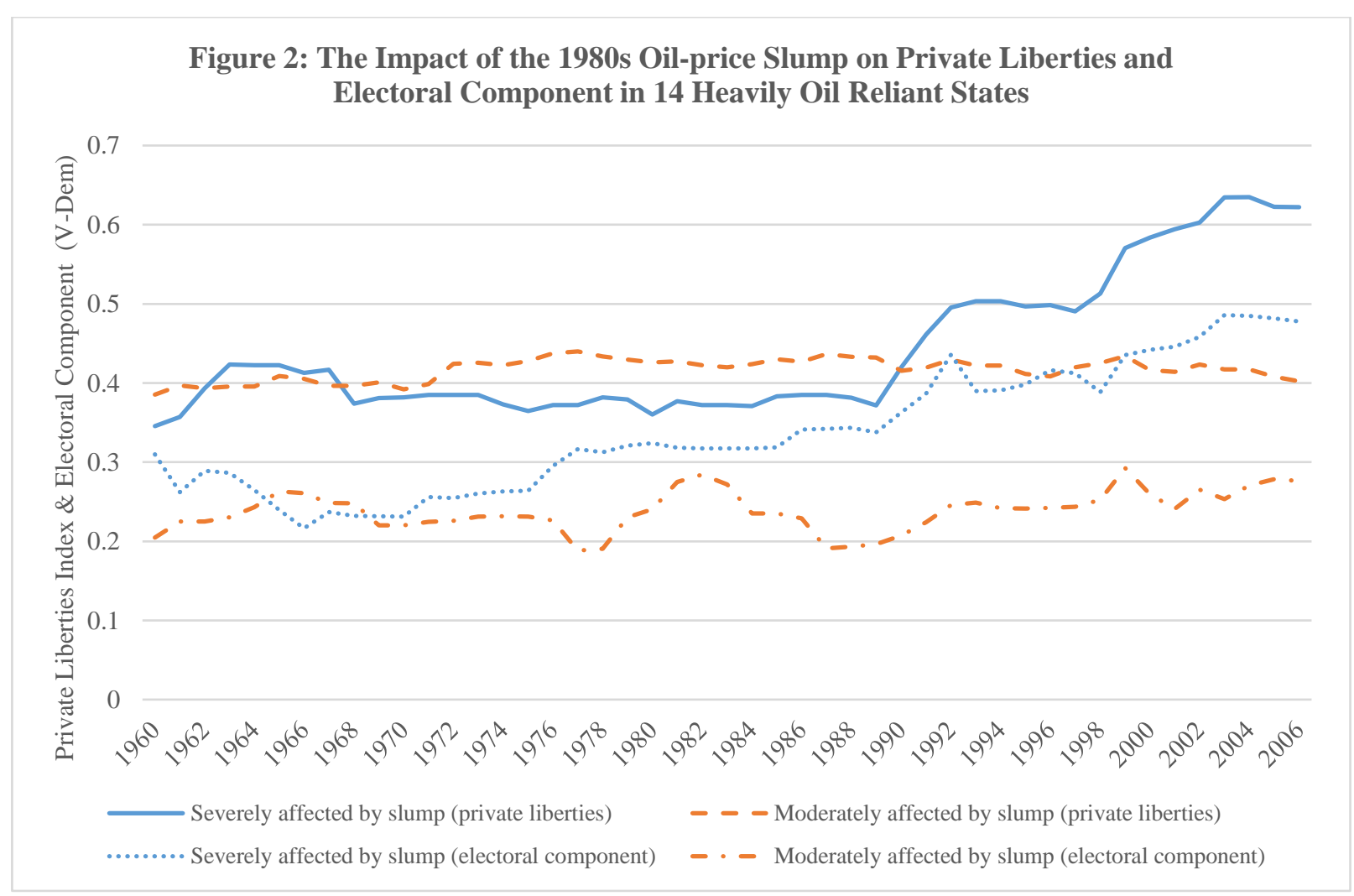

Nevertheless, these preliminary results are at best suggestive. It remains possible that there are factors (e.g. colonial past) other than the slide in oil revenues that explain the divergent trajectories of these two sets of states. In the panel data analysis that follows I take a number of steps to control for such factors and extend the sample to include nearly all states in the world dating back to the period when oil was first produced in significant quantities.

\footnotetext{
${ }^{6}$ In the online appendix I present the same graph, but replace the electoral component of democracy with legislative constraints on the executive (section A.4). I observe a similar trend, except that legislative constraints in those countries that were only moderately affected by the price slump decreased markedly after 1991.
} 


\section{Model, Variables, and Data}

\subsection{Model}

In order to test the claim that hydrocarbon rents lead to a reduction in private rights, I employ a panel of 162 countries for each year from 1932 to 2003. The estimation model takes the following form.

$y_{i t}=\beta_{0}+\beta_{1} \ln (\text { Oil Income })_{i t}+\beta_{2} \ln (X)_{i t}+\alpha_{2} E_{2}, \ldots, \alpha_{n} E_{n}+\delta_{2} T_{2}, \ldots, \delta_{t} T_{t}+u_{i t}$

Where $i$ is the country, $t$ is the year and $X$ is the set of control variables. In the baseline regressions I include country fixed-effects $\left(E_{2}, \ldots, E_{n}\right)$ in order to control for those unchanging or slowchanging factors, such as culture and inveterately weak state capacity, which may independently determine oil wealth and individual rights. In effect this means we are comparing each country with itself over time in order to see whether increases in the level of oil wealth are associated with decreases in the protection of private liberties. In addition, I include year dummies $\left(\mathrm{T}_{2}, \ldots, \mathrm{T}_{\mathrm{t}}\right)$ so as to control for the possibility of a spurious correlation between the dependent variable and independent variable of interest.

\subsection{Dependent Variables}

The dependent variables that are deployed in this study are the general private liberties index described above, as well as each of its sub-components, freedom from forced labor, property rights, freedom of domestic movement, and religious freedom. I also examine the impact of petroleum wealth on women's private liberties. This variable is based on the extent to which women have freedom of domestic movement, the right to private property, freedom from forced labor and access to justice (Coppedge et al. 2017; Sundström et al. 2017).

\subsection{Independent Variables}

\subsubsection{Petroleum Wealth}

The measure of natural resource wealth that I use in this study is the natural log (plus one) of total oil income per capita (in 2000 constant dollars), and is taken from the data set constructed by Ross and Mahdavi (2015). That variable is calculated by dividing the total value of a country's oil and natural gas production by its midyear population. This represents a more accurate indicator of oil rents than oil exports divided by GDP because it includes oil and gas that is produced and consumed domestically. Moreover, measuring petroleum rents in terms of export dependence may exaggerate the impact of oil and gas in poorer and conflict-ridden countries. 
Those countries are less able to consume the oil they extract, due to lower demand and reduced refining capacity. Similarly, the denominator is population rather than GDP so as to avoid indirectly measuring the size of each country's economy (Ross 2012, 15-16).

\subsubsection{Control Variables}

Petroleum wealth is dependent on exogenous factors such as geological endowment, largely exogenous factors such as oil prices, and endogenous factors such as exploratory effort. It is possible, therefore, that an omitted factor is simultaneously determining oil income and private liberties. I endeavor to address the possibility of omitted-variable bias by including country fixed-effects.

The fixed-effect specification helps to control for the omission of time-invariant factors that might independently determine oil income and the protection of private liberties. Nevertheless, it remains necessary to control for those time-varying factors that might also jointly determine exploratory effort and extraction rates, as well as private liberties. For that reason I include the natural log of GDP per capita and urbanization, in order to control for economic wealth and development. ${ }^{7}$ In order to control for the potentially confounding effect of war, I also include two dummy variables that indicate whether a country is experiencing a civil conflict (internal war) or an international conflict (international war). ${ }^{8}$

I also include an indicator of exploratory effort so as to further control for the endogeneity of oil flows. Exploratory effort is measured in terms of the number of wildcat wells drilled each year (in hundreds). Wildcat boreholes are drilled outside of known oilfields and are, therefore, used to detect the presence of undiscovered deposits. Thus, including this indicator of exploratory effort enables us to isolate the impact of oil income from the most geologically obvious and accessible locations (Menaldo 2016, 280). ${ }^{9}$

\subsubsection{Instrumental Variables}

It is also possible that the type of government institutions implied by the level of rights-protection in each country at least partially determines the level of petroleum wealth. Victor Menaldo (2016), for example, argues that countries that are characterized by poor quality institutions are

\footnotetext{
${ }^{7}$ Gross domestic product per capita (in 1990 international Geary-Khamis dollars) is taken from the Maddison Project (Bolt and van Zanden 2014). The share of population living in urban areas is taken from V-Dem Project (Coppedge et al. 2017).

${ }^{8}$ Those two variables are taken from the V-Dem project (Coppedge et al. 2017).

${ }^{9}$ The data source for this variable is Cotet and Tsui (2013).
} 
more likely to produce governments that are autocratic and that seek hydrocarbon rents. In order to address the possibility of endogeneity bias, I employ two instruments for oil income. The aim in both cases is to identify exogenous variation in oil income. The first instrument is the natural $\log$ (plus one) of cumulative total oil barrels (in million barrels of oil equivalent) associated with giant oil and gas fields in each country (geological endowment). Giant oil or gas fields contain at least 500 million barrels of oil equivalent that can ultimately be recovered. Discovering such fields is significantly easier than discovering smaller fields, which require substantial exploratory efforts. Thus, this represents the most exogenous (time-varying) measure of geological endowment (Menaldo 2016, 280-81). ${ }^{10}$

The second instrument uses the natural log of out-of-region natural disasters to proxy for price increases (out-of-region disaster). The underlying assumption for this variable is that a disaster affecting an oil-producing country (e.g. a hurricane in the Gulf of Mexico) will increase oil prices and, thereby, the oil income of those oil producers that are not affected by the disaster. Disaster damage for the affected country and region is excluded because it may directly influence political institutions via the declaration of a state of emergency or the movement of refugees to neighboring countries. This instrument was originally used by Ramsay (2011) to investigate the political resource curse. Unlike Ramsay, however, I retain country fixed-effects so as to control for the ability of large oil-producers such as Saudi Arabia to increase production in response to unexpected interruptions to the global supply of oil (Menaldo 2016, 63-64). ${ }^{11}$

\subsection{Multiple Imputation}

After building the data set it became apparent that observations were missing for a non-trivial proportion of country-years (see table A.2.1 in the online appendix). Deleting those cases with missing values may deprive the model of relevant information. Moreover, it may bias the results if there is a systematic difference between the observed and unobserved data. Thus, rather than applying the method of listwise deletion, I use multiple imputation to estimate the missing values (Honaker and King 2010). Using the multiple imputation process meant I was able to generate a balanced panel for 162 countries for the years 1932-2003. In order to ensure that the results are robust I also ran the baseline models using the original, non-imputed, data set (see section 8 below). Detailed variable descriptions, descriptive statistics, as well as a fuller explanation of the multiple imputation process are included in the online appendix.

\footnotetext{
${ }^{10}$ The data source for this variable is Horn (2015).

11 The data source for this variable is Cotet and Tsui (2013).
} 


\section{Results}

The results of the analysis are presented in table 1. Columns 1-5 present the Ordinary Least Squares regressions. The remaining columns present the Two-Stage Least Squares regressions with instrumental variables.

\subsection{Ordinary Least Squares (OLS)}

Columns 1-3 examine the influence of cross-country differences in the level of oil income on private liberties. As we can see from the bivariate model (column 1), oil income is negatively and significantly associated with private liberties. Column 2 includes a range of controls for fixed-factors. Those time-invariant controls are temperate climate, terrain ruggedness, ethnic fractionalization, Muslim, world region, legal origin. ${ }^{12}$ In column 3 the time-varying control variables are added to the regression. In both cases the independent variable of interest retains the expected sign and is significant at the $1 \%$ level.

Columns 4-5 examine the influence of changes in oil income within a country on private liberties. As we can see oil income retains the expected sign and achieves significance when country fixed-effects are included in the specification (column 4). That result holds after the time-varying covariates are included in the regression (column 5).

There is some disagreement among scholars over whether the hypothesized resource curse (or blessing) is best understood in terms of the impact of average levels of petroleum wealth on political outcomes (e.g. whether resource-rich countries are associated with less rightsprotection than resource-poor countries), or in terms of the impact of changes in the level of petroleum wealth in a country on political outcomes in that country (Wright et al, 2015:293294). Those scholars who are skeptical about the existence of a political resource curse typically argue that we should examine the within-country effect of hydrocarbon rents. Here I remain neutral regarding this debate and find evidence of a negative association between oil wealth and private rights, both between and within countries over time. Nevertheless, I prefer the results

\footnotetext{
12 Temperate climate is the share of the population living in a temperate climate zone (Gallup, Mellinger, and Sachs 2010); terrain ruggedness is the average unevenness of a country's terrain (Nunn and Puga 2012); ethnic fractionalization is the probability that two randomly chosen individuals from the same population belong to the same ethnic group (Alesina et al. 2003); Muslim is percentage of the population that adheres to that belief system (McCleary and Barro 2003); world region is a dummy variable based on the World Bank's classification; and legal origin is a dummy variable indicating the historical basis of each country's legal system (La Porta et al. 1999).
} 
obtained using country fixed-effects because that specification represents a more effective strategy for addressing the possibility of omitted-variable bias.

Some scholars argue that inclusion of control variables such as GDP per capita effectively eliminates the indirect positive impact of petroleum wealth on political outcomes (e.g. via economic growth) (Herb 2005). A comparison between the models with and without the timevarying controls (columns $1 \& 4$ versus columns $3 \& 5$ ) suggests that the net effect of oil income on private liberties is negative. As we will now see this is confirmed when the instrumental variables are included in the model specification (column $6 \mathrm{~b}$ versus column $7 \mathrm{~b}$ ). 
Table 1: Petroleum Wealth and Private Liberties

\begin{tabular}{|c|c|c|c|c|c|c|c|c|c|c|c|c|c|c|}
\hline & (1) & (2) & (3) & (4) & (5) & (6a) & (6b) & $(7 a)$ & (7b) & (8b) & (9b) & $(10 \mathrm{~b})$ & (11b) & (12b) \\
\hline Estimation strategy & OLS & OLS & OLS & OLS & OLS & $\begin{array}{l}\text { IV 2SLS } \\
\text { First stage }\end{array}$ & IV 2SLS & $\begin{array}{l}\text { IV 2SLS } \\
\text { First stage }\end{array}$ & IV 2SLS & IV 2SLS & IV 2SLS & IV 2SLS & IV 2SLS & IV 2SLS \\
\hline Dependent variable & & Private & liberties index & & & $\begin{array}{l}\text { Oil income } \\
\text { (ln) }\end{array}$ & $\begin{array}{c}\text { Private } \\
\text { liberties } \\
\text { index }\end{array}$ & $\begin{array}{l}\text { Oil income } \\
\text { (ln) }\end{array}$ & $\begin{array}{c}\text { Private } \\
\text { liberties } \\
\text { index }\end{array}$ & $\begin{array}{c}\text { Freedom } \\
\text { from forced } \\
\text { labor }\end{array}$ & $\begin{array}{l}\text { Property } \\
\text { rights }\end{array}$ & $\begin{array}{c}\text { Freedom of } \\
\text { domestic } \\
\text { movement }\end{array}$ & $\begin{array}{l}\text { Religious } \\
\text { freedom }\end{array}$ & $\begin{array}{l}\text { Women's } \\
\text { private } \\
\text { liberties }\end{array}$ \\
\hline Oil income (ln) & $\begin{array}{c}-0.0115^{* * *} \\
(0.00370)\end{array}$ & $\begin{array}{c}-0.0116^{* * *} \\
(0.00367)\end{array}$ & $\begin{array}{c}-0.0161 * * * \\
(0.00364)\end{array}$ & $\begin{array}{c}-0.0117 * * * \\
(0.00375)\end{array}$ & $\begin{array}{l}-0.0160 * * * \\
(0.00372)\end{array}$ & & $\begin{array}{c}-0.0105^{* *} \\
(0.00449)\end{array}$ & & $\begin{array}{c}-0.0144 * * * \\
(0.00462)\end{array}$ & $\begin{array}{c}-0.0106^{* * *} \\
(0.00244)\end{array}$ & $\begin{array}{c}-0.0121 * * * \\
(0.00270)\end{array}$ & $\begin{array}{c}-0.0111^{* * *} \\
(0.00350)\end{array}$ & $\begin{array}{c}-0.0837^{* * *} \\
(0.0179)\end{array}$ & $\begin{array}{c}-0.0119 \text { *** } \\
(0.00339)\end{array}$ \\
\hline GDP per capita (ln) & & & $\begin{array}{l}0.0247^{*} \\
(0.0133)\end{array}$ & & $\begin{array}{l}0.0239 * \\
(0.0134)\end{array}$ & & & $\begin{array}{c}0.706^{* * *} \\
(0.0604)\end{array}$ & $\begin{array}{l}0.0224 * * * \\
(0.00664)\end{array}$ & $\begin{array}{c}-0.0183^{* * *} \\
(0.00651)\end{array}$ & $\begin{array}{l}0.00977^{*} \\
(0.00536)\end{array}$ & $\begin{array}{c}0.0271 * * * \\
(0.00658)\end{array}$ & $\begin{array}{c}0.170 * * * \\
(0.0317)\end{array}$ & $\begin{array}{c}0.0292^{* * *} \\
(0.00584)\end{array}$ \\
\hline Urbanization (ln) & & & $\begin{array}{c}0.240^{* * *} \\
(0.0887)\end{array}$ & & $\begin{array}{l}0.245^{* * *} \\
(0.0924)\end{array}$ & & & $\begin{array}{l}0.746^{* *} \\
(0.294)\end{array}$ & $\begin{array}{c}0.244 * * * \\
(0.0603)\end{array}$ & $\begin{array}{c}0.295^{* * *} \\
(0.0705)\end{array}$ & $\begin{array}{c}0.140^{* * *} \\
(0.0503)\end{array}$ & $\begin{array}{l}0.118^{* *} \\
(0.0532)\end{array}$ & $\begin{array}{c}0.567 * * \\
(0.247)\end{array}$ & $\begin{array}{c}0.266^{* * *} \\
(0.0532)\end{array}$ \\
\hline International war & & & $\begin{array}{c}-0.0408^{* *} \\
(0.0161)\end{array}$ & & $\begin{array}{c}-0.0403^{* *} \\
(0.0161)\end{array}$ & & & $\begin{array}{c}-0.282^{* * *} \\
(0.0676)\end{array}$ & $\begin{array}{c}-0.0397 * * * \\
(0.0117)\end{array}$ & $\begin{array}{l}-0.0207^{* *} \\
(0.00908)\end{array}$ & $\begin{array}{c}-0.0119 \\
(0.00819)\end{array}$ & $\begin{array}{c}-0.0402^{* * *} \\
(0.0112)\end{array}$ & $\begin{array}{c}-0.185^{* * *} \\
(0.0613)\end{array}$ & $\begin{array}{c}-0.0290 * * * \\
(0.00885)\end{array}$ \\
\hline Internal war & & & $\begin{array}{c}-0.0330^{* * *} \\
(0.0128)\end{array}$ & & $\begin{array}{c}-0.0328^{* *} \\
(0.0127)\end{array}$ & & & $\begin{array}{c}0.0120 \\
(0.0458)\end{array}$ & $\begin{array}{c}-0.0328^{* * *} \\
(0.00968)\end{array}$ & $\begin{array}{l}-0.0237^{* *} \\
(0.00935)\end{array}$ & $\begin{array}{l}-0.0138^{*} \\
(0.00717)\end{array}$ & $\begin{array}{c}-0.0541^{* * *} \\
(0.00903)\end{array}$ & $\begin{array}{c}-0.112^{* *} \\
(0.0433)\end{array}$ & $\begin{array}{c}-0.0295^{\text {*** }} \\
(0.00722)\end{array}$ \\
\hline Exploratory effort & & & $\begin{array}{c}0.00140 \\
(0.000982)\end{array}$ & & $\begin{array}{c}0.00143 \\
(0.000999)\end{array}$ & & & $\begin{array}{l}0.00839 * \\
(0.00442)\end{array}$ & $\begin{array}{l}0.00140 * * \\
(0.000688)\end{array}$ & $\begin{array}{l}-0.000643 \\
(0.000583)\end{array}$ & $\begin{array}{c}0.000742 \\
(0.000611)\end{array}$ & $\begin{array}{l}0.0000157 \\
(0.000652)\end{array}$ & $\begin{array}{c}0.0119 * * * \\
(0.00335)\end{array}$ & $\begin{array}{r}0.000815 \\
(0.000609)\end{array}$ \\
\hline $\begin{array}{l}\text { Temperate climate } \\
\text { Terrain ruggedness } \\
\text { Ethnic fractionalization } \\
\text { Muslim }\end{array}$ & & $\begin{array}{c}0.151 * * * \\
(0.0402) \\
-0.0388^{* * *} \\
(0.00870) \\
0.0446 \\
(0.0543) \\
-0.101 * * \\
(0.0474)\end{array}$ & $\begin{array}{c}0.0954^{* *} \\
(0.0430) \\
-0.0311^{* * *} \\
(0.00881) \\
0.0158 \\
(0.0536) \\
-0.0842^{*} \\
(0.0463)\end{array}$ & & & & & & & & & & & \\
\hline $\begin{array}{l}\text { Geological endowment (ln) } \\
\text { Out-of-region disaster }(\ln )\end{array}$ & & & & & & $\begin{array}{c}0.357 * * * \\
(0.0167) \\
2.697 * \\
(1.391)\end{array}$ & & $\begin{array}{l}0.332^{* * *} \\
(0.0153) \\
3.600^{* *} \\
(1.513)\end{array}$ & & & & & & \\
\hline Year dummies & $\checkmark$ & $\checkmark$ & $\checkmark$ & $\checkmark$ & $\checkmark$ & $\checkmark$ & $\checkmark$ & $\checkmark$ & $\checkmark$ & $\checkmark$ & $\checkmark$ & $\checkmark$ & $\checkmark$ & $\checkmark$ \\
\hline $\begin{array}{l}\text { Country fixed-effects } \\
\text { World region dummies } \\
\text { Legal origin dummies }\end{array}$ & & $\begin{array}{l}\checkmark \\
\checkmark\end{array}$ & $\begin{array}{l}\checkmark \\
\checkmark\end{array}$ & $\checkmark$ & $\checkmark$ & $\checkmark$ & $\checkmark$ & $\checkmark$ & $\checkmark$ & $\checkmark$ & $\checkmark$ & $\checkmark$ & $\checkmark$ & $\checkmark$ \\
\hline $\begin{array}{l}\text { Legal origin dummies } \\
\text { Countries }\end{array}$ & 162 & $\begin{array}{c}\checkmark \\
162\end{array}$ & $\begin{array}{c}\checkmark \\
162\end{array}$ & 162 & 162 & 162 & 162 & 162 & 162 & 162 & 162 & 162 & 162 & 162 \\
\hline Years & $1932-2003$ & $1932-2003$ & $1932-2003$ & $1932-2003$ & $1932-2003$ & $1932-2003$ & $1932-2003$ & $1932-2003$ & $1932-2003$ & $1932-2003$ & $1932-2003$ & $1932-2003$ & $1932-2003$ & $1932-2003$ \\
\hline Observations & 11664 & 11664 & 11664 & 11664 & 11664 & 11664 & 11664 & 11664 & 11664 & 11664 & 11664 & 0.573 & 0.203 & 0.968 \\
\hline Hansen J statistic & & & & & & & 0.765 & & 0.990 & 0.528 & 0.509 & 0.573 & 0.203 & 0.968 \\
\hline Kleibergen-Paap rk statistic & & & & & & & 244.4 & & 263.1 & 263.1 & 263.1 & 263.1 & 263.1 & 263.1 \\
\hline
\end{tabular}

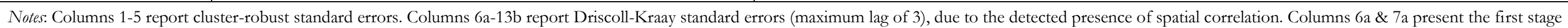
regressions. Columns $6 \mathrm{~b} \& 7 \mathrm{~b}-12 \mathrm{~b}$ present the second stage regressions. For columns $7 \mathrm{~b}-12 \mathrm{~b}$ the first stage regression is the same as $7 \mathrm{a}$. *** significant at $1 \%$; $* * 5 \%$; $* 10 \%$ 


\subsection{Instrumental Variables Two-Stage Least Squares (IV 2SLS)}

The remaining columns in the table employ IV 2SLS regressions to address the possibility of endogeneity bias. In each case oil income is instrumented with geological endowment and outof-region disaster. Both instruments, as well as the control variables, are included in the first stage of the regression as predictors of oil income. The second stage regression estimates the coefficient for oil income based on the first stage regression. Each regression includes country and year fixed-effects. Columns $6 \mathrm{a}$ and $6 \mathrm{~b}$ present the regressions for the first stage and second stage regressions for the bivariate specification. Columns $7 \mathrm{a}$ and $7 \mathrm{~b}$ present the regressions for the first stage and second stage regressions for the specification that includes the time-varying controls. As we can see the results in both cases are consistent with the results we obtained for the OLS models. In addition, the Kleibergen-Paap Wald F-stat and Hansen p-values indicate that the two instruments are sufficiently correlated with the potentially endogenous regressor (oil income) and that they are not directly correlated with the dependent variable (private liberties). This suggests they are strong and valid instruments for oil income (this remains the case for the remaining 2SLS results in table 1).

Columns $8 \mathrm{~b}-11 \mathrm{~b}$ present the second-stage regressions for each of the four subcomponents of the private liberties index - freedom from forced labor, property rights, freedom of domestic movement, and religious freedom. In each case the first stage regression is identical to $7 \mathrm{a}$. As we can see oil income carries the expected sign for each sub-component. Column 12b examines the relationship between oil income and women's private liberties. As we can see oil wealth is negatively associated with this index of women's rights. This result complements Michael Ross's (2008) finding that oil rents are negatively associated with female labor force participation and female members of parliament (see also Liou and Musgrave 2016). ${ }^{13}$

\section{Further Robustness Checks}

In table 2 I return to the OLS estimation method in order to further test the results. Columns 1 examines whether the baseline results hold when an alternative measure of private liberties is employed. That indicator is taken from CIRI Human Rights data set, which provides data on individual rights as far back as 1981 (Cingranelli, Richards, and Clay 2014). The private rights index that I use is the sum of four CIRI indicators, freedom of domestic and foreign movement, workers' rights, and freedom of religion. The index ranges from 0 (no government respect for all these rights) through to 8 (full government respect for all these rights). As we can see from

\footnotetext{
${ }^{13}$ The OLS regressions for each of those indices are included in the online appendix, section A.6.
} 
column 1, petroleum wealth is negatively associated with that measure of private liberties. However, I prefer to rely on the measures of private liberties that have been constructed by the V-Dem project because they encompass the entire period since countries began to produce economically significant amounts of oil. In addition, the V-Dem variables are based on the responses of multiple country experts, and so they are less susceptible to measurement error (Skaaning 2009).

Table 2: Further Robustness Checks

\begin{tabular}{|c|c|c|c|c|c|c|c|}
\hline & (1) & (2) & (3) & (4) & (5) & (6) & $(7)$ \\
\hline Dependent variable & $\begin{array}{l}\text { Private rights } \\
\text { index }(C I R I)\end{array}$ & $\begin{array}{c}\text { Private } \\
\text { liberties index }\end{array}$ & $\begin{array}{c}\text { Private } \\
\text { liberties index }\end{array}$ & $\begin{array}{c}\text { Private } \\
\text { liberties index }\end{array}$ & $\begin{array}{c}\text { Private } \\
\text { liberties index }\end{array}$ & $\begin{array}{c}\text { Private } \\
\text { liberties index }\end{array}$ & $\begin{array}{c}\text { Private } \\
\text { liberties index }\end{array}$ \\
\hline Oil income (ln) & $\begin{array}{c}-0.161 * * \\
(0.0684)\end{array}$ & & & & $\begin{array}{c}-0.0167 * * * \\
(0.00403)\end{array}$ & & \\
\hline Oil reserves $(\ln )$ & & $\begin{array}{c}-0.0327^{* * *} \\
(0.0103)\end{array}$ & & & & $\begin{array}{c}-0.0340^{* * *} \\
(0.0117)\end{array}$ & $\begin{array}{c}-0.0350 * * \\
(0.0157)\end{array}$ \\
\hline Total fuel income $(\ln )$ & & & $\begin{array}{c}-0.0218 * * * \\
(0.00394)\end{array}$ & & & & \\
\hline Oil producer & & & & $\begin{array}{c}-0.0927 * * * \\
(0.0199)\end{array}$ & & & \\
\hline GDP per capita (ln) & $\begin{array}{c}0.221 \\
(0.195)\end{array}$ & $\begin{array}{c}0.0136 \\
(0.0130)\end{array}$ & $\begin{array}{c}0.0307 * * \\
(0.0137)\end{array}$ & $\begin{array}{c}0.0185 \\
(0.0129)\end{array}$ & $\begin{array}{c}0.0170 \\
(0.0139)\end{array}$ & & $\begin{array}{l}0.00303 \\
(0.0315)\end{array}$ \\
\hline Urbanization (ln) & $\begin{array}{l}0.0489 \\
(0.268)\end{array}$ & $\begin{array}{c}0.265^{* * *} \\
(0.0918)\end{array}$ & $\begin{array}{l}0.302 * * * \\
(0.0921)\end{array}$ & $\begin{array}{c}0.249 * * * \\
(0.0920)\end{array}$ & $\begin{array}{c}0.329 * * * \\
(0.0952)\end{array}$ & & $\begin{array}{c}0.538^{* *} \\
(0.220)\end{array}$ \\
\hline International war & $\begin{array}{l}-0.431 \\
(0.299)\end{array}$ & $\begin{array}{c}-0.0371 * * \\
(0.0157)\end{array}$ & $\begin{array}{c}-0.0317^{* *} \\
(0.0157)\end{array}$ & $\begin{array}{c}-0.0368^{* *} \\
(0.0159)\end{array}$ & $\begin{array}{c}-0.0373 * * \\
(0.0184)\end{array}$ & & $\begin{array}{c}-0.0563^{* *} \\
(0.0253)\end{array}$ \\
\hline Internal war & $\begin{array}{c}-0.274^{*} \\
(0.165)\end{array}$ & $\begin{array}{c}-0.0324 * * \\
(0.0125)\end{array}$ & $\begin{array}{c}-0.0361 * * * \\
(0.0126)\end{array}$ & $\begin{array}{c}-0.0331 * * * \\
(0.0126)\end{array}$ & $\begin{array}{c}-0.0347 * * \\
(0.0140)\end{array}$ & & $\begin{array}{c}-0.0413^{* *} \\
(0.0189)\end{array}$ \\
\hline Exploratory effort & $\begin{array}{c}-0.00668 \\
(0.0120)\end{array}$ & $\begin{array}{l}0.00172 * \\
(0.00102)\end{array}$ & $\begin{array}{c}0.00133 \\
(0.000992)\end{array}$ & $\begin{array}{c}0.00168^{*} \\
(0.000993) \\
\end{array}$ & $\begin{array}{c}0.00168 \\
(0.00110)\end{array}$ & & $\begin{array}{l}0.00118^{* *} \\
(0.000573)\end{array}$ \\
\hline Year dummies & $\checkmark$ & $\checkmark$ & $\checkmark$ & $\checkmark$ & $\checkmark$ & $\checkmark$ & $\checkmark$ \\
\hline Country fixed-effects & $\checkmark$ & $\checkmark$ & $\checkmark$ & $\checkmark$ & $\checkmark$ & $\checkmark$ & $\checkmark$ \\
\hline Countries & 167 & 162 & 162 & 162 & 145 & 160 & 82 \\
\hline Years & $1981-2003$ & $1932-2003$ & $1932-2003$ & $1932-2003$ & $1932-2003$ & $1932-2003$ & $1932-2003$ \\
\hline Observations & 3841 & 11664 & 11664 & 11664 & 10440 & 9069 & 4889 \\
\hline
\end{tabular}

Notes: The estimation method is OLS. Cluster-robust standard clustered are reported in parenthesis. Column 5 excludes countries from the Middle East \& North Africa region. Columns $6 \& 7$ are based on the non-imputed data set. *** significant at $1 \%$; ** 5\%; * $10 \%$

For columns 2-3 I again take V-Dem's private liberties index as the dependent variable, but replace oil income with two alternative indicators of hydrocarbon wealth. In column 2 petroleum wealth is measured in terms of the natural log (plus one) of proven oil reserves per capita (in thousand million barrels). The source for this variable is Cotet and Tsui (2013). In column 3 petroleum wealth is measured in terms of the natural log (plus one) of total fuel income per capita (total value of petroleum, coal and natural gas produced, in 2007 dollars). This variable is taken from the data set constructed by Haber and Menaldo (2011). Reassuringly those indicators of natural resource abundance and income are negatively associated with private liberties. 
The oil income data is characterized by a nonnormal distribution because most countries produce little if any oil and gas, while a few produce vast quantities. In order to address the skewed distribution of the data I have taken the natural log of oil income. Nevertheless, the oil income values remain skewed after they have been log transformed. Thus, I also examine whether the baseline results hold when a dichotomous indicator of petroleum wealth is employed. According to that indicator, a country is identified as an oil producer if it realizes at least 100 dollars per capita (measured in constant 2000 dollars) in income from oil and gas in a particular year. The data source for this variable is Ross and Mahdavi (2015). As we can see from column 4 that measure of petroleum wealth is also negatively associated with private liberties.

Column 5 examines whether the countries in the Middle East \& North Africa region are driving the results. Reassuringly, I find that the negative association between oil income and private liberties holds when those countries are excluded from the sample.

Finally, I examined whether the results held when the baseline models were estimated using the non-imputed data set. I use oil reserves rather than oil income because less data is missing for that indicator of oil wealth. Reassuringly, the results are consistent with the baseline estimations, suggesting that they are not simply a product of the imputation process (see columns 6 and 7). However, I prefer to rely on the estimations produced by multiple imputation because that allows us to include more information and to avoid the possibility of selection bias (e.g. the listwise deletion of oil-rich states that afford more protection to private liberties, or oilpoor states that afford less protection to private liberties). This is of particular concern for the specification that includes the time-varying controls (column 7).

\section{Mediation Analysis}

In the theoretical section I proposed that oil wealth can affect the level of private liberties independently of its effect on the level of democracy. I argued that a significant increase in oil wealth undercuts the ability of citizens to bargain for the protection of their private rights and that governments can use that windfall to expand the coercive power of the state. This direct effect of oil wealth on private liberties is represented by the solid arrow in the diagram below. 


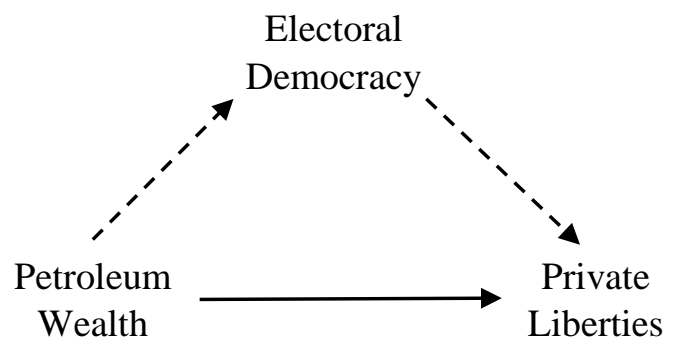

Critics may argue that the negative impact of oil wealth on private liberties runs via its impact on the level of democracy. That is to say, oil wealth leads to a reduction in the level of democracy, which undercuts the ability of citizens to demand the protection of their private rights. This indirect pathway is represented by the dashed arrows in the diagram above.

I use mediation analysis in order to examine those two causal explanations. More precisely, I examine whether oil wealth directly effects private liberties and, if so, the magnitude of that effect relative to its effect via the level of democracy. The mediation analysis was carried out based on the following pair of linear regressions:

$$
\begin{aligned}
& \text { Electoral democracy }_{i t}=\beta_{0}+\beta_{1} \text { Oil producer }_{i t}+\beta_{2} X_{i t}+\delta_{2} T_{2}, \ldots, \delta_{n} T_{n}+u_{i t} \\
& \text { Private Liberties }_{i t}=\theta_{0}+\theta_{1} \text { Oil producer }_{i t}+\theta_{2} \text { Electoral democracy }_{i t}+\theta_{3} X_{i t}+ \\
& \delta_{2} T_{2}, \ldots, \delta_{n} T_{n}+u_{i t}
\end{aligned}
$$

I measured petroleum wealth in terms of the dichotomous oil producer variable described in the previous section. The number of oil producers in the world - countries where oil income is greater than 100 dollars per capita - rose from 2 in 1932 to 45 in 2003. I constructed the mediator variable, electoral democracy, based on the degree of suffrage, free and fair elections, elected officials, and multiparty elections. Mediation analysis requires that there are no unmeasured confounders for both causal pathways (VanderWeele 2015, 24-26). Thus, I employ the same set of time-varying and time-invariant control variables that were used in the model without fixed effects (Table 1, column 3).

The counterfactual approach to mediation analysis outlined by Valeri and VanderWeele (2013) was used to produce three quantities of interest. The natural direct effect (NDE) expresses how much the outcome (private liberties) would change if the treatment (oil producer) were set at 1 rather than 0 , but for each unit in the population the mediator (electoral democracy) remains at the level it would have taken in the absence of the treatment. In our case this represents the average effect of a change from not being an oil producer to being an oil producer, holding electoral democracy at the level it would have taken if that change had not 
occurred. The natural indirect effect (NIE) expresses how much the outcome would change on average if the treatment were set at 1 , but the mediator was changed from the level it would take if the treatment was changed from 0 to 1 . In our case this quantity of interest reflects how much the level of private liberties changes only in response to changes in the mediator that are produced by a shift from not being an oil producer to being an oil producer. The total effect (TE) reflects how much the outcome would change overall if the treatment were changed from 0 to 1 . This quantity is equivalent to the sum of the natural direct effect and natural indirect effect.

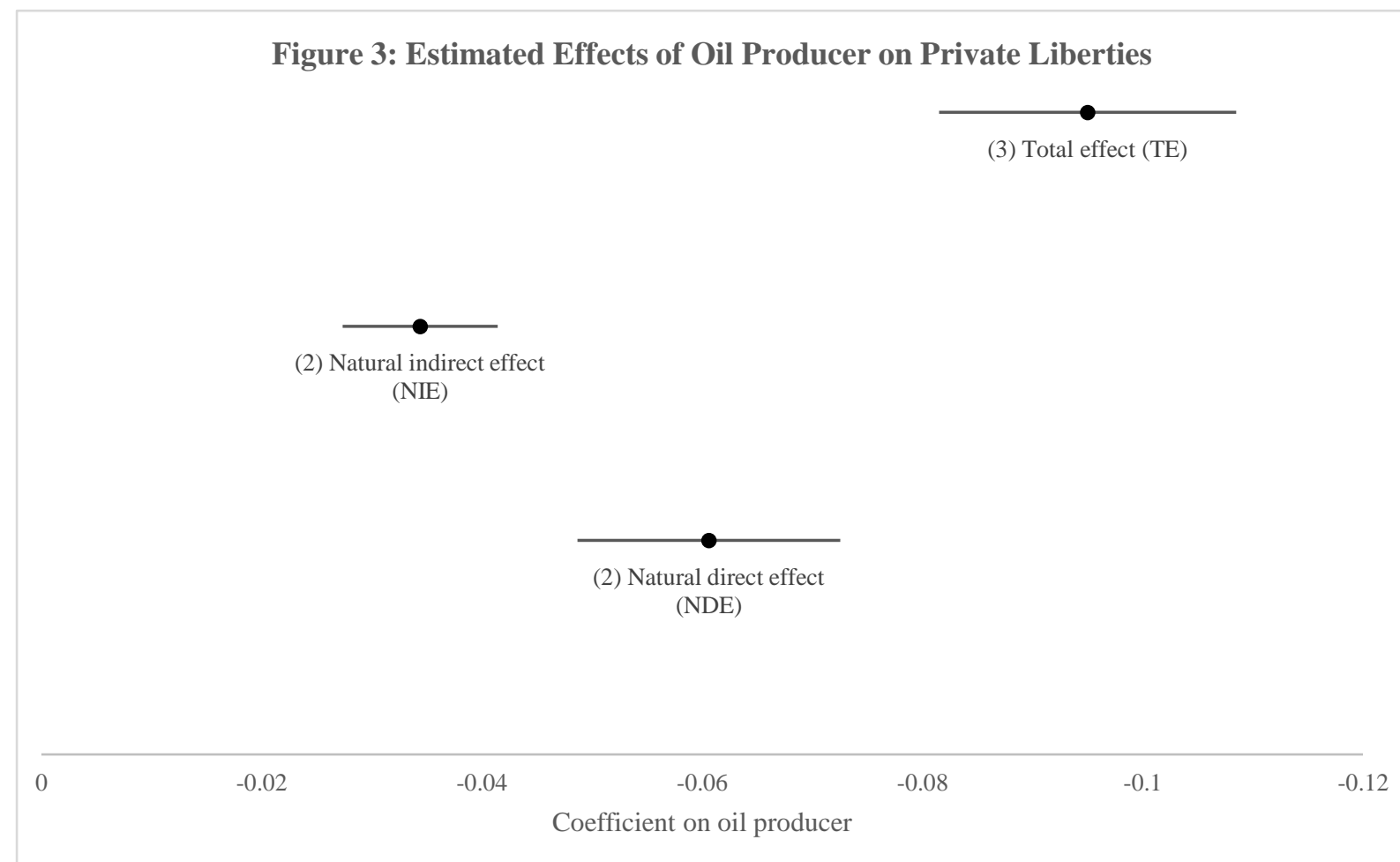

Notes: Lines represent $95 \%$ confidence intervals. The confidence intervals are based on the bootstrap process with 1000 resamples.

The results of the mediation analysis are presented in figure 3. Reassuringly, the coefficient for the total effect is similar to the coefficient for oil producer in table 2 (column 4 ). The coefficient for the natural indirect effect suggests that some of the impact of oil wealth on private liberties does run via its impact on the level of democracy. However, the coefficient for the natural direct effect represents $64 \%$ of the total effect of oil wealth on the private liberties index. ${ }^{14}$ This suggests that most of the effect of oil wealth on private rights is not a product of its effect on the level of democracy.

\footnotetext{
${ }^{14}$ I obtained similar results for each of the sub-components of the private liberties index, as well as the women's private liberties index. See online appendix, section A.7.
} 
It is worth noting that the magnitude of the direct effect is significantly greater for the Middle East \& North Africa and Europe \& Central Asia regions. The effect for each of those regions is double the average direct effect for all countries. This is significant given that $60 \%$ of the world's oil reserves are currently located in those two regions (British Petroleum 2016). ${ }^{15}$

\section{Conclusion}

The existing literature on the political resource curse focuses on the impact of hydrocarbon wealth on the quality of the democratic process, and especially the extent to which that process permits electoral participation and multi-party competition. In this study, by contrast, I have examined the impact of hydrocarbon wealth on the private rights of the individual. I argued that governments with access to sizable revenues from natural resources are subject to less pressure to enlarge the extent to which citizens are free from interference. In addition, they can use the resource windfall at their disposal to extend the coercive capacity of the state.

In order to test that claim I employed a new data set of political indicators that is less susceptible to the methodological shortcomings that afflict the indices that have been used in previous studies. Based on a panel of 162 countries for the years 1932-2003 I have found that petroleum wealth is negatively associated with private liberties. Moreover, that result holds when a number of steps are taken to address the endogeneity of oil flows. This is crucial given the claim of curse skeptics that some states are historically predisposed to both become autocratic and to pursue oil rents. This result also holds when alternative measures of petroleum wealth and private liberties are employed. Finally, I have presented evidence that most of the effect of petroleum wealth on private liberties arises independently of its effect on the level of democracy. That finding reinforces the central claim of this article, that the political resource curse extends beyond representation to include the private rights of the individual.

\footnotetext{
15 There is also an, albeit lower, negative direct effect for the remaining world regions, except for Sub-Saharan Africa. In the latter case the direct effect is positive and the total effect is negative, indicating that the (negative) indirect effect outweighs the direct effect for that region. This sensitivity analysis was carried out by including an interaction term for oil producer and each region in the mediation analysis.
} 


\section{References}

Alesina, Alberto, Arnaud Devleeschauwer, William Easterly, Sergio Kurlat, and Romain Wacziarg. 2003. "Fractionalization.” Journal of Economic Growth 8 (2): 155-94. doi:10.1023/A:1024471506938.

Andersen, J. J., and M. L. Ross. 2014. "The Big Oil Change: A Closer Look at the HaberMenaldo Analysis.” Comparative Political Studies 47 (7): 993-1021. doi:10.1177/0010414013488557.

Bolt, Jutta, and Jan Luiten van Zanden. 2014. "The Maddison Project: Collaborative Research on Historical National Accounts." The Economic History Review 67 (3): 627-651. doi:10.1111/1468-0289.12032.

British Petroleum. 2016. "Statistical Review of World Energy 2016." version. http://www.bp.com/statisticalreview.

Cingranelli, David L, David L Richards, and K. Chad Clay. 2014. "The CIRI Human Rights Dataset." Data set. CIRI Human Rights Data Project. http://www.humanrightsdata.com.

Coppedge, Michael, John Gerring, David Altman, Michael Bernhard, Steven Fish, Allen Hicken, Matthew Kroenig, et al. 2011. "Conceptualizing and Measuring Democracy: A New Approach.” Perspectives on Politics 9 (02): 247-67. doi:10.1017/S1537592711000880.

Coppedge, Michael, John Gerring, Staffan I. Lindberg, Svend-Erik Skaaning, Jan Teorell, David Altman, Michael Bernhard, et al. 2017. "V-Dem [Country-Year/Country-Date] Dataset V7." Data set. Varieties of Democracy (V-Dem) Project. https://www.vdem.net/en/data/data-version-7/.

Coppedge, Michael, John Gerring, Staffan I. Lindberg, Svend-Erik Skaaning, Jan Teorell, Joshua Krusell, Kyle L. Marquardt, et al. 2017a. "“V-Dem Methodology V7.”" Data set. Varieties of Democracy (V-Dem) Project. https://www.v-dem.net/en/data/dataversion-7/.

Cotet, Anca M, and Kevin K Tsui. 2013. "Oil and Conflict: What Does the Cross Country Evidence Really Show?” American Economic Journal: Macroeconomics 5 (1): 49-80. doi:10.1257/mac.5.1.49.

Dahl, Robert A. 1991. Democracy and Its Critics. Yale University Press. 
Egorov, Georgy, Sergei Guriev, and Konstantin Sonin. 2009. "Why Resource Poor Dictators Allow Freer Media: Theory and Evidence from Panel Data.” American Political Science Review 103 (4): 645-68.

Gallup, John L., Andrew D. Mellinger, and Jeffrey D. Sachs. 2010. “Geography Datasets.”

Center for International Development Dataverse. http://hdl.handle.net/1902.1/14429.

Haber, Stephen, and Victor Menaldo. 2011. "Do Natural Resources Fuel Authoritarianism? A Reappraisal of the Resource Curse.” American Political Science Review 105 (01): 126. doi:10.1017/S0003055410000584.

Herb, Michael. 2005. "No Representation without Taxation? Rents, Development, and Democracy." Comparative Politics 37 (3): 297. doi:10.2307/20072891.

Honaker, James, and Gary King. 2010. "What to Do About Missing Values in Time-Series Cross-Section Data.” American Journal of Political Science 54 (2): 561-81.

Horn, Myron K. 2015. "Giant, Supergiant \& Megagiant Oil and Gas Fields of the World." Data set. https://edx.netl.doe.gov/dataset/aapg-datapages-giant-oil-and-gas-fields-ofthe-world.

La Porta, Rafael, Florencio Lopez-de-Silanes, Andrei Shleifer, and Robert Vishny. 1999. “The Quality of Government." Journal of Law, Economics, and Organization 15 (1): 222-79. doi:10.1093/jleo/15.1.222.

Levi, Margaret. 1989. Of Rule and Revenue. Berkeley: University of California Press.

Liou, Yu-Ming, and Paul Musgrave. 2014. "Refining the Oil Curse: Country-Level Evidence from Exogenous Variations in Resource Income." Comparative Political Studies 47 (11): 1584-1610. doi:10.1177/0010414013512607.

. 2016. "Oil, Autocratic Survival, and the Gendered Resource Curse: When Inefficient Policy Is Politically Expedient.” International Studies Quarterly 60 (3): 440-56. doi:10.1093/isq/sqw021.

Mahdavy, Hossein. 1970. “The Patterns and Problems of Economic Development in Rentier States: The Case of Iran." In Studies in Economic History of the Middle East, edited by M.A. Cook, 428-67. London: Oxford University Press.

McCleary, Rachel M, and Robert J. Barro. 2003. "Religion Adherence Data.” Data set. https://scholar.harvard.edu/mccleary/data-sets.

Menaldo, Victor. 2016. The Institutions Curse: Natural Resources, Politics, and Development. Cambridge: Cambridge University Press.

Munck, Gerardo L., and Jay Verkuilen. 2002. "Conceptualizing and Measuring Democracy: Evaluating Alternative Indices." Comparative Political Studies 35 (1): 5-34. 
North, Douglass C., and Barry R. Weingast. 1989. "Constitutions and Commitment: The Evolution of Institutions Governing Public Choice in Seventeenth-Century England.” The Journal of Economic History 49 (4): 803-32.

Nunn, Nathan, and Diego Puga. 2012. “Country Ruggedness and Geographical Data.” Data set. http://diegopuga.org/data/rugged/.

O’Donnell, Guillermo, and Philippe C. Schmitter. 1986. Transitions from Authoritarian Rule: Tentative Conclusions about Uncertain Democracies. Baltimore: Johns Hopkins University Press.

Ramsay, Kristopher W. 2011. "Revisiting the Resource Curse: Natural Disasters, the Price of Oil, and Democracy." International Organization 65 (03): 507-29. doi:10.1017/S002081831100018X.

Richter, Thomas, and Viola Lucas. 2016. “GSRE 1.0 - Global State Revenues and Expenditures Dataset.” GESIS Data Archive. https://doi.org/10.7802/1290.

Ross, Michael L. 2008. “Oil, Islam, and Women.” The American Political Science Review 102 (1): 107-23.

. 2012. The Oil Curse: How Petroleum Wealth Shapes the Development of Nations. Princeton University Press.

—. 2015. "What Have We Learned about the Resource Curse?” Annual Review of Political Science 18 (1): 239-59. doi:10.1146/annurev-polisci-052213-040359.

Ross, Michael L., and Passha Mahdavi. 2015. “Oil and Gas Data, 1932-2014.” Data set. Harvard Dataverse. http://dx.doi.org/10.7910/DVN/ZTPW0Y.

Skaaning, Svend-Erik. 2009. "Measuring Civil Liberty: An Assessment of Standards-Based Data Sets." Revista de Ciencia Politica 29 (3): 721-40.

Sundström, Aksel, Pamela Paxton, Yi-Ting Wang, and Staffan I. Lindberg. 2017. "Women's Political Empowerment: A New Global Index, 1900-2012.” World Development 94 (Supplement C): 321-35. doi:10.1016/j.worlddev.2017.01.016.

Vadlamannati, Krishna Chaitanya, and Indra De Soysa. 2016. "Do Resource-Wealthy Rulers Adopt Transparency-Promoting Laws?” International Studies Quarterly 60 (3): 45774. doi:10.1093/isq/sqw026.

Valeri, Linda, and Tyler J. VanderWeele. 2013. "Mediation Analysis Allowing for ExposureMediator Interactions and Causal Interpretation: Theoretical Assumptions and Implementation with SAS and SPSS Macros." Psychological Methods 18 (2): 137-50. doi:10.1037/a0031034. 
VanderWeele, Tyler. 2015. Explanation in Causal Inference: Methods for Mediation and Interaction. 1 edition. New York: Oxford University Press.

Wright, Joseph, Erica Frantz, and Barbara Geddes. 2015. "Oil and Autocratic Regime Survival." British Journal of Political Science 45 (2): 287-306. doi:10.1017/S0007123413000252. 